\title{
紙パルプ用脱水機* \\ 一ロータリープレスフィルター
}

巴工業株式会社 営業技術部第二課 松 本 光 司

\section{Dewatering Machine for Paper and Pulp \\ -Rotary Press Filter-}

\section{Kouji Matsumoto}

Process Engineering Development section Machinery \& Equipment Division

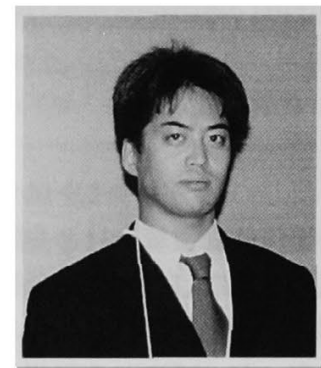

Rotary Press Filter is a rotational pressurized dewatering machine that has a unique dewatering mechanism. It was developed by CRIQ, the industrial research center in Quebec, Canada and manufactured and distributed by Fournier Industries Inc. Tomoe Engineering Co., Ltd. started its production under their license this year (2002).

Feature of Rotary Press are : 1) High-dewaterability, 2) A simple structure, 3) A tight-sealed structure that prevent odor emission, 4) A small foot print, 5) Less enegy cost, 6) Easy and minimal maintenance works. It meets needs of today and future.

We have already installed 14 units (including sewerage application) in Japan and installed 3 units in 2 paper making plants for their wastewater sludge treatment. Further, we are conducting dewatering tests on respective applications with our test machine and have been obtaining good results. We will introduce the Rotary Press Filter for pulp \& paper industry.

分類： $\mathrm{J}_{1}$ パルプ精選・洗净・濃縮一般, $\mathrm{J}_{0}$ その他

\section{1.はじめに}

ロータリープレスフィルタはカナタのケベック工業 研究所 (CRIQ) により開発され, 同国フォーニア社 により製造，販売されている新しい脱水機構を持つ回 転加圧脱水機である。2002 年からは巴工業侏で国産 を開始した。高い脱水性能を有し，機構が簡単，密閉 構造で臭気の発生がない,コンパクトでエネルギーコ ストを低滅でき維持管理性に優れているため，これか らの時代に合致した脱水機と考えられる。現在，日本

*平成 14 年度年次大会講演（講演 No. D 8)
国内だけで24台（下水含む）の納入実績を有し，製 紙工場排水污泥向けにも2 所（3台）の納入実績が ある。また，奏験機による各種処理物の脱水実験も継 続して実施しており良好な結果が得られている。

本稿では, 紙パルプ業界向けのロータリープレスフ ィルタの機器について紹介する。

\section{2. 機 構}

ロータリープレスフィルタの機構図を図1に示す。

・駆動軸と共に回転する金属円盤フィルタと内輪ス ペーサ, 静止している外輪スペーサによりろ室が 形成される。原液はこのろ室内に圧入され，ろ過 


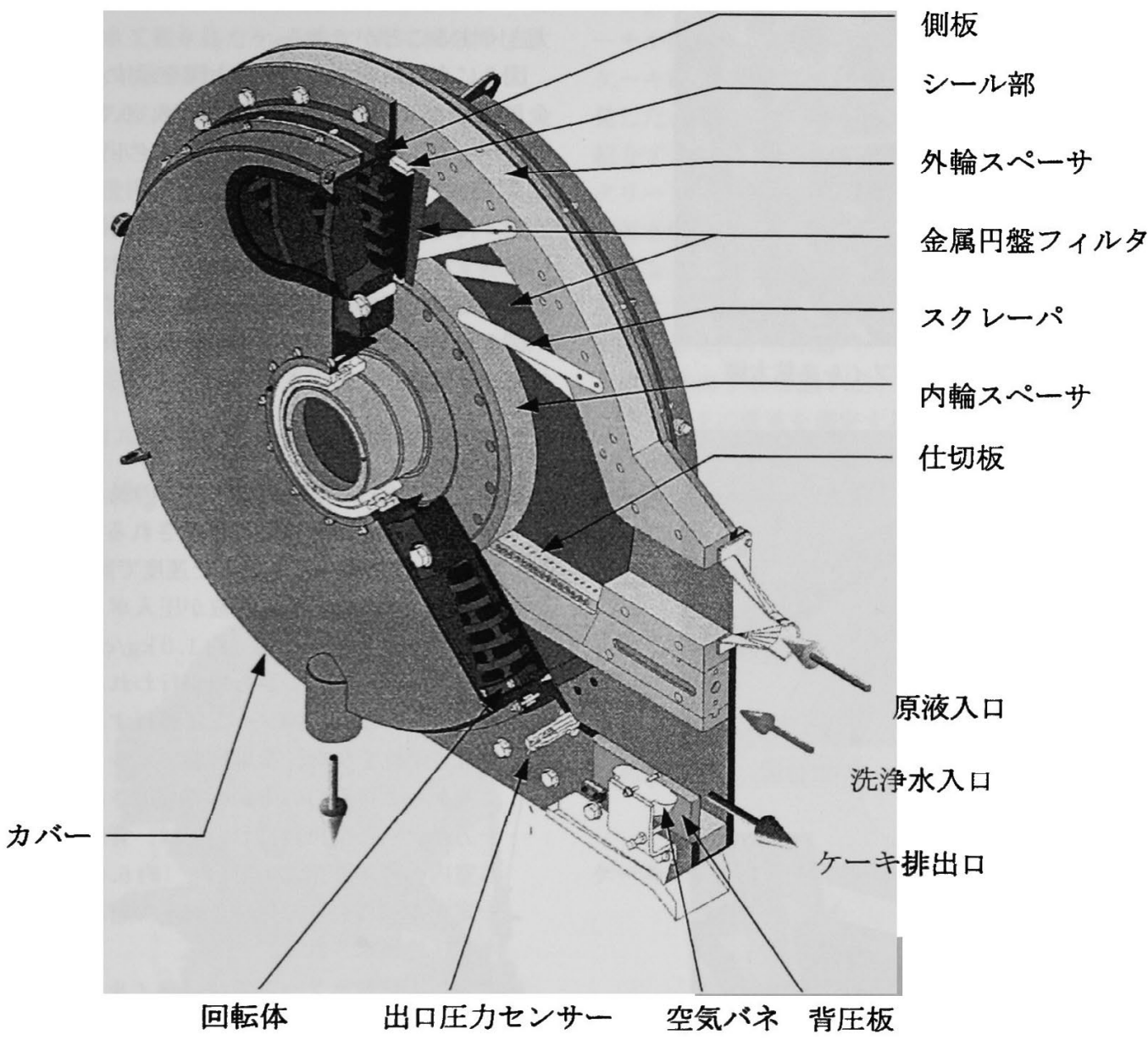

図1ロータリープレスフィルタ機構図

- 脱水される。

・金属円盤フィル夕の両側にはカバーがついており, ここでろ液を捕集し機外へ排出する。また，カバ 一と外輪スペーサ及びシール部により金属フィル 夕は密閉されている。

・ロータリープレスフィルタの供給ラインには入口 压力七ンサーがついており，常に入口圧力を検知 している。

・ケーキ排出部には出口圧力七ンサーがついており, ここで压力を検知して出口圧力が設定値になるよ うに空気バネの圧縮空気量を調整し，背圧板がケ 一キを圧搾する強さを変化させる，

- 入口付近の外輪スペーサに取り付けられたスクレ 一パによって, フィルタ面に付着した固形物が掻 き取られ,フィルタ面が再生される。

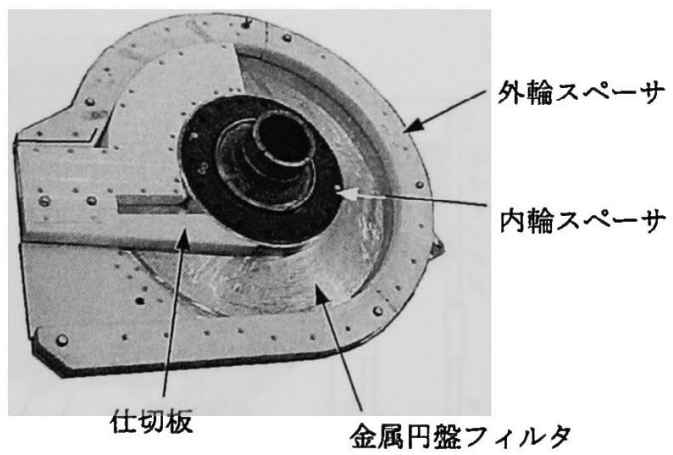

図 2 ロータリープレスフィルタ分解図

図 2 にロータリープレスフィルタ分解図を示す。内 輪スペーサ，金属円盤フィル夕，外輪スペーサおよび 仕切板によってろ室が形成される。内輪スペーサ，外 


松本光司

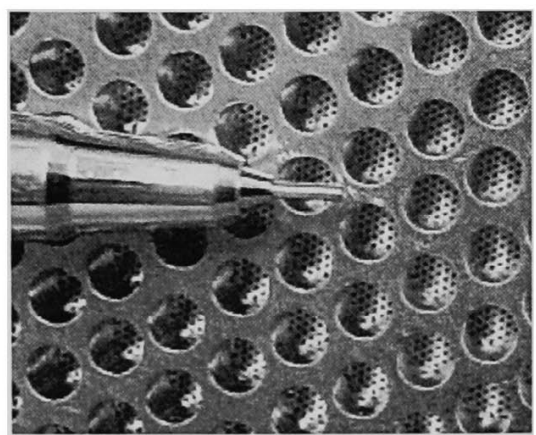

図 3 金属円艋フィルタ拡大図

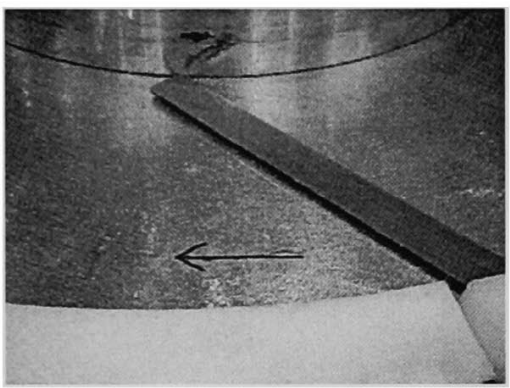

図４スクレーパ取付図

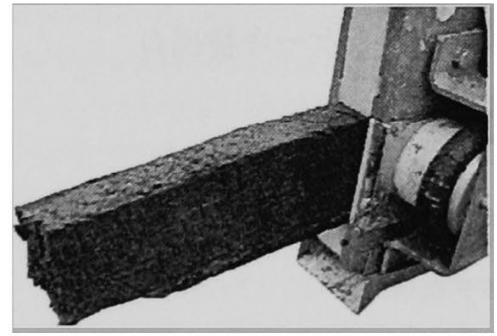

図 5 ケーキ排出部

輪スペーサおよび仕切板の幅を変更することでろ室を 大きくすることができる。

図 3 に金属円盤フィルタ拡大図を示す。微細な穴が 金属円盤フィルタで, 孔径は $0.18 ， 0.25 ， 0.38$ の 3 種類がある。手前の穴は金属円盤フィルタを支えるバ ックアッププレートである。

図4にスクレーパ取付図を示す。金属円盤フィルタ に接触するように，スクレーパが取付けてある。なお 矢印は金属円盤フィルタの回転方向を示す。

図 5 にケーキ排出図を示す。脱水ケーキは背圧板を 押し退けて危害に排出される。

\section{3. 脱水原理}

図6にロータリーブレスフィルタの脱水機構を示す。 ・金属円盤フィルタにより形成されるろ室が 0.5 1.3 min-1 のゆっくりとした速度で回転する。

・ろ過ゾーンにおいて，原液が圧入ポンプにより， ろ室内に最大 $100 \mathrm{kPa}$ (約 $1.0 \mathrm{~kg} / \mathrm{cm} 2$ ) の圧力 で連続供給され，初期ろ過が行われる。

・ ろ過ゾーンから压搾ゾーンに移行する過程で, 原 液は流動性を失い, 金属円盤フィル夕の回転力に よりケーキ排出口の方向へ押し出される。

・一方，ヶーキ排出口においては，背圧板により， 万室内の背圧が最大 $600 \mathrm{kPa}\left(\right.$ 約 $\left.6.0 \mathrm{~kg} / \mathrm{cm}^{2}\right)$ の 一定圧力 (可変) で保持されその背圧によりヶー キが压䇽脱水される。

・さらに压搾脱水ゾーンでは, フィル夕面の水分の 低下したケーキは回転速度に見合って排出口へ移 動されるが, 万室外側部分の比較的水分の高いケ 一キは, フィル夕面のケーキとの間にスリップが 生じ, その速度差で発生するせん断力により脱水

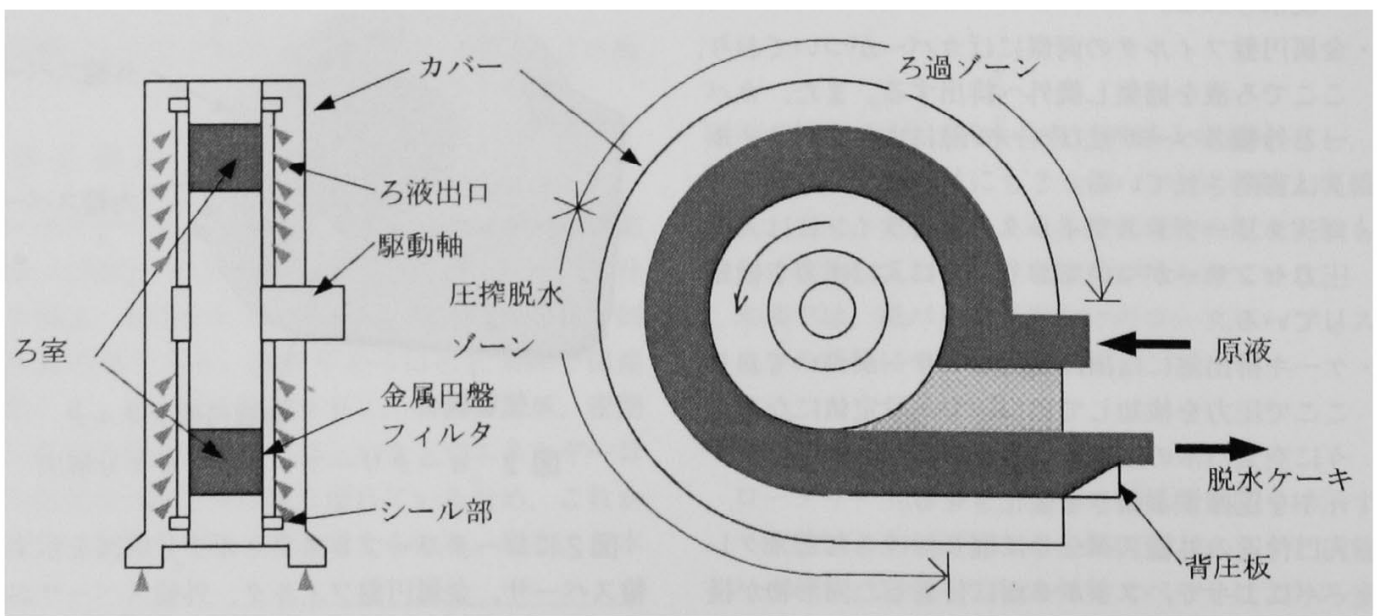

図 6 ロータリーブレスフィルタ脱水機構 
が促進される。

・一連の脱水工程を経たケーキは, 背圧板を押し退 けて機外へ排出される。

・分離液はろ室の両側に設けたカバーで捕集され， 機外へ排出される。

・運転中の洗浄は原則として不要であり，運転終了 時に約 5〜10 分間程度の洗浄で十分である。スク レーパはろ過ゾーンに取り付けてあり, フィルタ 面に付着した固形物は原液から排出される水分に よって軟化され，運転中でも容易にフィル夕面が 再生されるためである。

4. バーチカルリストリクタ

金属円盤フィル夕の回転で固形物を搬送しているこ
とは前章で述べたが，処理物によっては脱水機内でヶ 一キが閉塞する現象が起こることがあった。そこで， ケーキ排出部を改造したバーチカルリストリク夕を開 発した。この章ではバーチカルリストリクタについて 紹介する。図7(b)にバーチカルリストリク夕型ロー タリープレスの外観図を示す。

脱水原理は変わらないが, 背圧板が従来のものと全 く異なった形状となっている。通常, バーチカルリス トリクタは空気バネの働きによってケーキ排出部を密 閉しており，ケーキはバーチカルリストリタタを押し 退けて排出される図7(c)。しかし，ロータリープレ スフィルタの荷重を測定するロードセルに設定値以上 の荷重がかかると, 空気バネがパーチカルリストリク 夕を図7(a)のように開放し機内のケーキを排出しや

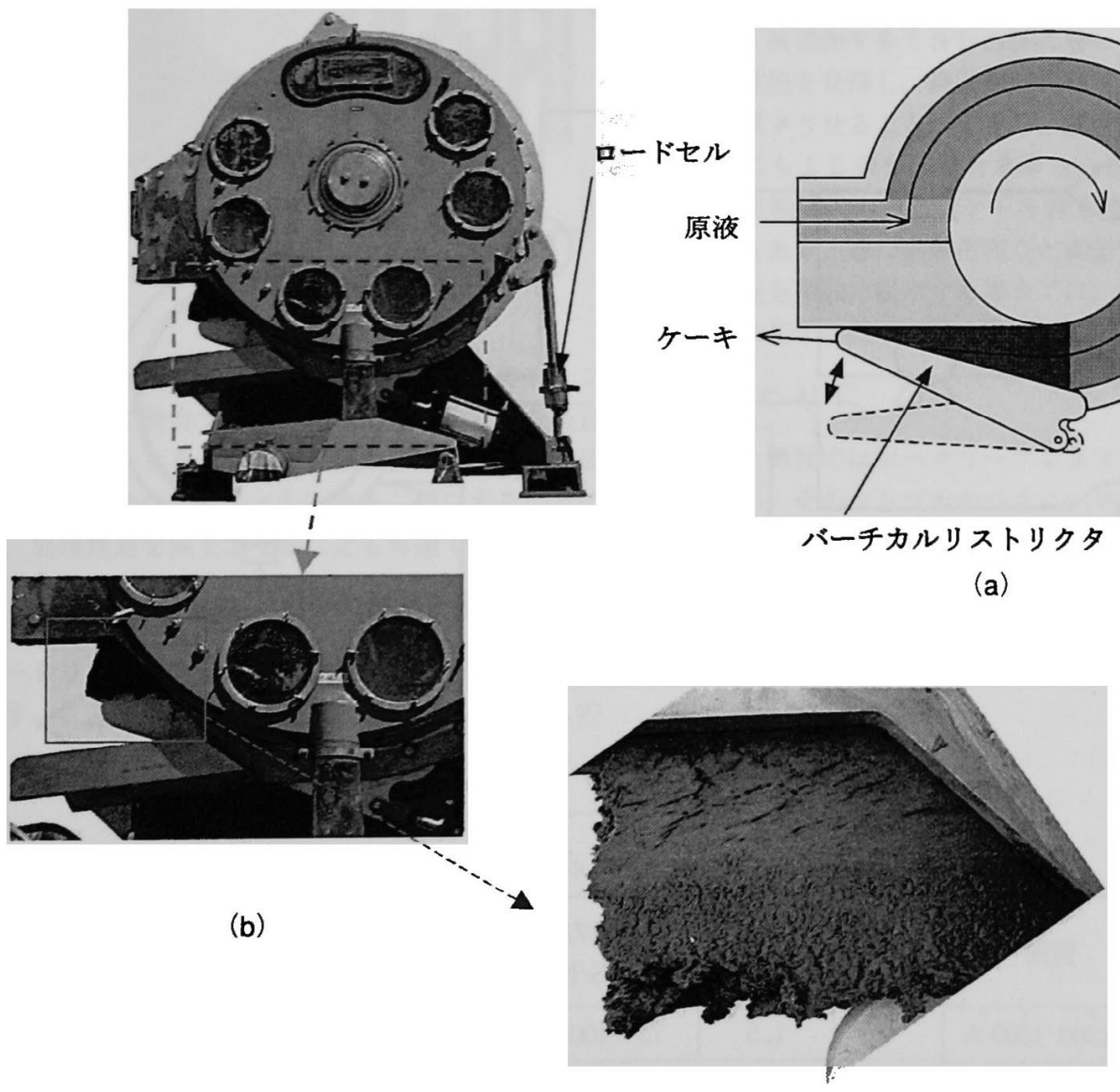

(c)

(a) バーチカルリストリクタ動作イメージ図

（b）バーチカルリストリクタ型ロータリープレス外観図

(c) 脱水ヶーキ排出状況

図 7 


松本光司

すくする構造となっている。これによりケーキの閉塞 を防止し，安定した連続処理を可能とした。

\section{5. ロータリープレスフィルタの特徴}

ロータリーブレスフィルタは以下の特徴を有してい る。

(1) 始動，停止に特別な工程を必要とせず，構造が シンプルで構成部品も少ないため, 運転・維持管 理が容易である。

(2) $\phi 1200$ 機では 1 から 6 チャンネルまでの機種 があり，チャンネルの増設が容易であるため幅広 い処理量に対応できる

3. 密閉構造であるため臭気漏れがない。

4 本体回転数は 0.5 1.3 $\mathrm{min}^{-1}$ と遅く，振動・騒
音もない。さらに所要動力はわずかである。

(5) 金属円盤フィル夕表面の微細孔部面積が小さく, フィルタ厚が薄いことから目詰まりがなく, 洗浄 水量はわずかである。必要洗浄水量は $\phi 1,200 \mathrm{~mm}$ が1チャンネル当たり 130〜 $180 \mathrm{l} / \mathrm{min}$ であり， 停止時に 5 10 分程度の洗浄を行うのみで, 運転 中の洗浄は原則として必要としない。

(6) 入口圧力一定制御の採用により, 污泥性状・濃 度変動等に対し，安定した運転が行える。

6. ロータリープレスフィルタ処理フロー

ロータリープレスフィルタの処理フローを図8に示 す。原液はモーノポンプにてフロキュレータに供給し, そこからロータリープレスフィルタに供給する。凝集

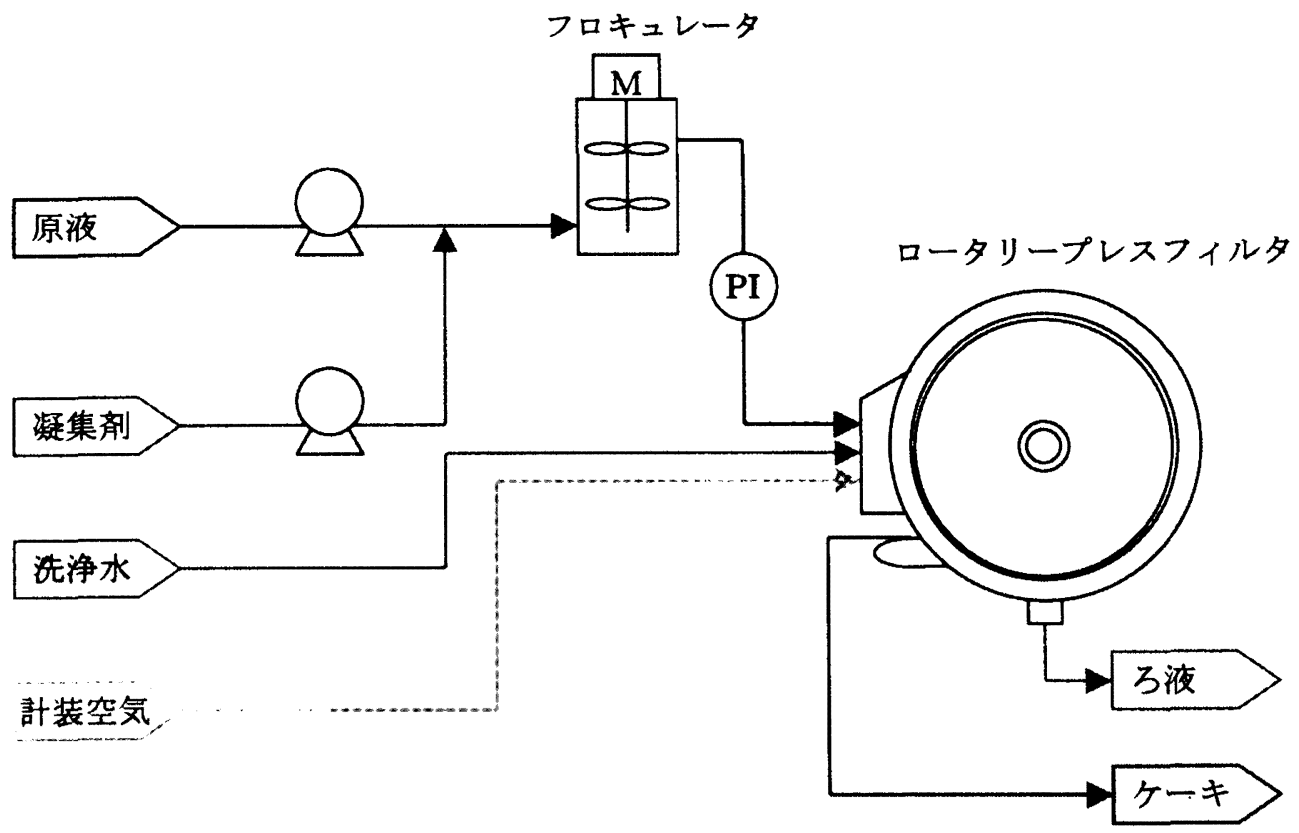

図８ロータリープレスフィルタ処理フロー

表 1 ロータリープレスフィルタの仕様と処理能力

\begin{tabular}{|c|c|c|c|c|c|c|c|c|}
\hline \multirow{2}{*}{ 機種 } & \multirow{2}{*}{$\begin{array}{c}\text { 乃室数 } \\
(-)\end{array}$} & \multirow{2}{*}{$\begin{array}{c}\text { 万過面積 } \\
\left(\mathrm{m}^{2}\right)\end{array}$} & \multirow{2}{*}{$\begin{array}{c}\text { 処理能力 } \\
(\mathrm{kg}-\mathrm{DS} / \mathrm{h})\end{array}$} & \multicolumn{3}{|c|}{ 寸法(m) } & \multirow{2}{*}{$\begin{array}{l}\text { 質量 } \\
(\mathrm{T})\end{array}$} & \multirow{2}{*}{$\begin{array}{l}\text { 電動機 } \\
(\mathrm{kW})\end{array}$} \\
\hline & & & & 長さ & 全幅 & 高さ & & \\
\hline $1-1200 / 1500 \mathrm{~A}$ & 1 & 1.5 & $75 \sim 400$ & 2.2 & 1.1 & 1.9 & 3.0 & 3.7 \\
\hline $2-1200 / 3000 \mathrm{~A}$ & 2 & 3.0 & $150 \sim 800$ & 2.5 & 1.8 & 1.9 & 5.4 & 7.5 \\
\hline $4-1200 / 6000 \mathrm{~A}$ & 4 & 6.0 & $300 \sim 1,600$ & 2.8 & 3.0 & 1.9 & 11.3 & 11.0 \\
\hline $6-1200 / 9000 \mathrm{~A}$ & 6 & 9.0 & $450 \sim 2,400$ & 2.8 & 4.0 & 1.9 & 15.3 & 18.5 \\
\hline
\end{tabular}

注：処理能力は製紙工場排水污泥を記载 
表 2 製紙工場排水実験データ

\begin{tabular}{c|c|c|c|c}
\hline & ケーキ含水率 & SS 回収率 & ポリマー薬注率 & 既設機との比較 \\
\hline $\mathrm{A}$ 社総合排水 & 57 & 99 & $\begin{array}{c}0.17 \text { (カチオン) } \\
0.08 \text { (アニオン) }\end{array}$ & $3 \sim 7 \%$ 低下 \\
\hline $\mathrm{B}$ 社総合排水 & 53 & 98 & 0.21 & $7 \sim 13 \%$ 低下 \\
\hline $\mathrm{C}$ 社総合排水 & 60 & 99 & 0.4 & $4 \sim 6 \%$ 低下 \\
\hline $\mathrm{D}$ 社総合排水 & 49 & 99 & 0.15 & $3 \sim 5 \%$ 低下 \\
\hline
\end{tabular}

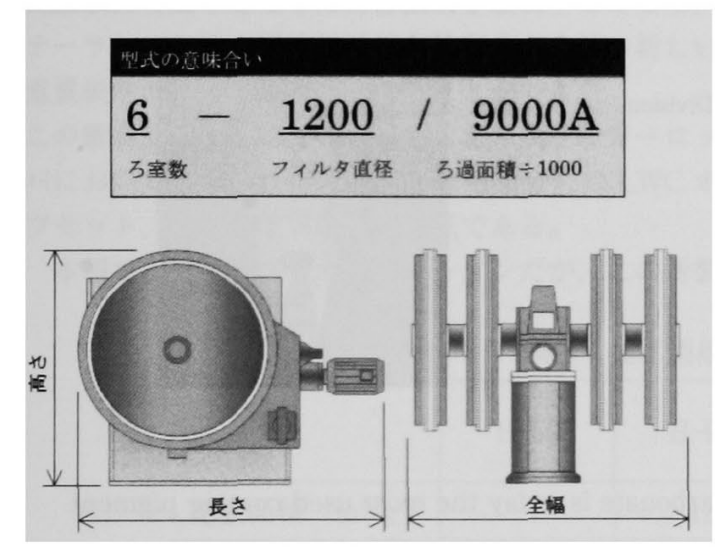

図9ロータリープレスフィルタ仕様

荗は, フロキュレータ手前で污泥ラインに供給し，フ ロキュレータで混合する。無薬注で処理が可能な場合 はフロキュレータを含む薬注設備は必要なく、二液法 を採用する場合はフロキュレータを二段にすることに より，処理性能を向上させることも可能である。

\section{7. ロータリプレスフィルタの仕様と処理能力}

ロータリプレスフィル夕の仕様及び処理能力を表 1 に示す。ここでは, フィル夕直径が $1,200 \mathrm{~mm}$ のもの
を示したが，他にも $300 \mathrm{~mm}, 600 \mathrm{~mm}$ の機種もある。 図9にロータリープレスフィルタ仕様を示す。

8. 処理能力

ロータリープレスフィルタは, 縺維質を多く含む処 理物の脱水に特に有効である。製紙工場排水の場合, パルプや無機物を多く含む污泥に対しては非常に優れ た処理性能を発揮し，既設機に比べて大幅にケーキ含 水率を低下させることができる。混合污泥ではその混 合比率にもよるがケーキ含水率 50〜 $60 \%$ が見込め, 弊社の実験結果の中にはケーキ含水率が $40 \%$ になる データもある。逆に余剩污泥など織維質をあまり含ま ない污泥を単独で脱水する場合では, 既設機に比べて 含水率は若干の低下に留まっている（表 2)。

\section{9. おわりに}

現在, 慗社ではロータリープレスフィルタによる実 験を行い, そのシンブルかつユニークな脱水機棈及び 高い脱水性能は評価を頂いている。また，処理性能向 上を目的とした開発実験を継続して行っており, 今後 紙パルプの業界でロータリープレスフィルタが役に立 てることを期待している。 


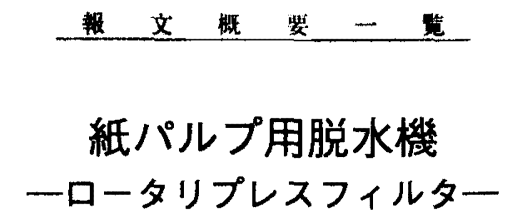

巴工業株式会社 営業技術部第 2 課 松本 光司

ロータリブレスフィルタはカナタのケベック工業研究所（CRIQ）により開発され, 同国フォーニヤ 社により製造、眅売されている新しい脱水機構を持つ回転加圧脱水機である。2002 年からは巴工業株 式会社で国産を開始した。高い脱水性能を有し, 機棈が簡単, 密閉棈造で臭気の発生がない,コンパク トでエネルギーコストを低減でき維持管理性に優れているため,これからの時代に合致した脱水機と考 えられる。現在日本国内だけで 14 台（下水含む）の納入実績を油脂, 製紙工場排水污泥向けにも， 2 ヶ所（3台）の納入実績がある。また，奏駼機による各種処理物の脱水実験も継続して実施しており， 良好な結果が得られている。本稿ではロータリブレスフィルタの機棈, 脱水原理について紹介する。ま た、製紙排水污泥の脱水の際に起こった問面を解決した，バーチカルリストリクタ型のロータリブレス フィルタの機楆、脱水原理及びこれまでに実際に行った実験データを他機種との比較を交えて紹介する。

(本文 40 ページ)

\section{「カバカーブ」（ハイドロカーブ CC）}

一光学的性質を増すために開発された新しい塗工用重質炭酸カルシウム一

\section{Omya $\mathrm{AG}$ ギレルモ ブルボール}

製界での湿式重質炭酸カルシウムは每年飛躍的に伸びている塗工顔料で色々の紙に使用されてい 万。

塗工用顔料としての湿式重カルは現在まで高白色度,バインター最低減，塗工機のランナビリティー， オフセット印刷適性, 経济性等の好果が期待されてきたが, しかし使用用途によっては不透明性, 鿵蔽 性が低く、クロスの点では限界がある。

OMYA 社は粒子の光散乱性に関する理論から，光散乱保数を简くする，即ち粒度分布をシャープに し, 理想の不透明性をもたらし，かつ湿式重カルが持つ多くの品質の優位性を批なわなくする染工顔料 を粉砕技術で調整することにより、この問題を解決した。これが7 年前に開発され、現在 100 万トン(ス ラリー) まで著しく伸びた商品“カバカーブである。この特殊な顔料の生産能力を新规に增大する計 画で進んでいる。

本報において、“カバカーブについての説明と従来の湿式重カルとの比較をLWC 配合（ウェブオ フセット)，コート紙（シンクル塗工），及び塗工板紙（タフル\&トリプル）にて例証する。

(本文 46 ページ)

\section{環境に配慮した紙パ用染料・薬品の展開}

株式会社日本化菓カラース 市場開発 SC タルーフ 菅谷 邦夫

環境問題が叫ばれて久しいが，今や企業にとって環境への対応は当然のこととされている。

日本化楽も「生命と健康を守り，崫かな暮らしを文える製品と技術で人類に貢献し続ける会社」を基

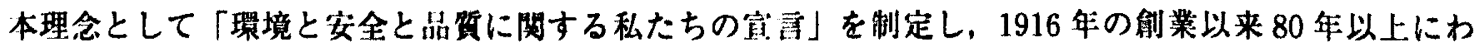
たり事業を推進してきている。 